\title{
Improving Quality and Yield Production of Coconut Shell Charcoal Through a Modified Pyrolysis Reactor with Tar Scrubber to Reduce Smoke Pollution
}

\author{
Reka Mustika Sari ${ }^{1}$, Saharman Gea ${ }^{1 *}$, Basuki Wirjosentono ${ }^{1}$, Sunit Hendrana ${ }^{2}$, \\ Yasir Arafat Hutapea ${ }^{1}$
}

${ }^{1}$ Department of Chemistry, Faculty of Mathematics and Natural Sciences, Universitas Sumatera Utara, Medan, Indonesia ${ }^{2}$ Research Centre for Chemistry, Indonesian Institute of Sciences, Tangerang Selatan, Banten, Indonesia

Received: 10 May 2019

Accepted: 9 July2019

\begin{abstract}
The two main problems faced by the conventional coconut shell charcoal industry are low charcoal yield and smoke pollution. Therefore, the purpose of this study is to modify the pyrolysis reactor equipped with tar scrubbers as a solution to the problem of smoke pollution and yield, and improve the quality of charcoal. A reactor of the size $2.4 \times 1.2 \times 1.2 \mathrm{~m}$ and the heat coming out of the rocket stove can be blown from the bottom, thus it can propagate evenly through a perforated plate. The reactor was designed with circulating pipes as places for channeling non-condensable gases to be used as fuel. Produced charcoal yield rose from $23 \%$ to $28 \%$ and the quality of charcoal fulfilled SNI requirements and those of the Republic of Indonesia Ministry of Energy and Mineral Resources. The morphology of charcoal and mineral composition in SEM-EDX showed an increase in the composition of carbon elements by $83.63 \%$. The FTIR spectrum results decrease in the broad intensity of $\mathrm{O}-\mathrm{H}$ and the charcoal structure produced was amorphous. The total pore volume was $0.07336 \mathrm{cc} / \mathrm{g}$ and the pore surface area was $12.716 \mathrm{~m}^{2} / \mathrm{g}$. This modified reactor with tar scrubber produces better yield, and minimal smoke pollution compared to traditional combustion of charcoal.
\end{abstract}

Keywords: charcoal yield, coconut shell, pyrolysis, smoke pollution, tar scrubber

\section{Introduction}

Nowadays, the increasing of waste produced by humans to the atmosphere and the environment has

*e-mail: s.gea@usu.ac.id

caused great effect on the environment and human health. Industrial activity is the greatest air polluter [1]. The emission of toxic substances into the environment is vastly spreading, especially from the smoke of the charcoal industry.

In the charcoal industry, one of the unsolved problems is smoke pollution resulting from burning charcoal. Smoke is one of the causes of air pollution, 
which kills millions of people annually [2-4]. Charcoal combustion pollutants produce carcinogenic compounds such as formaldehyde, which is one of the causes of nasopharyngeal tumors [5]. The smoke mixture also contains gas, which consists of $\mathrm{CO}(20-22 \%), \mathrm{H}_{2}$ (10$\left.12 \%), \mathrm{CH}_{4}(1-2 \%)\right), \mathrm{N}_{2}(50-55 \%)$, and $\mathrm{CO}_{2}(10 \%)$. Moreover, tar produced from biomass combustion can cause headache, dizziness, fatigue, and a loss of concentration [6-7].

The next problem is low charcoal yield. The presence of oxygen from the outside is a factor that influences the yield of charcoal obtained because the carbon formed in the presence of oxygen will experience a further reaction, namely oxidation, so that the end result will be ash with a low-quality charcoal [8-9]. Based on this weakness, the coconut shell charcoal industry really requires technology that is more environmentally friendly and can increase the yield and quality of charcoal significantly.

One solution offered is to utilize a pyrolysis technology. The combustion system is carried out by heating biomass raw materials to reach temperatures of $400-600^{\circ} \mathrm{C}$ with a long residence time of 5 to 30 minutes, causing gas-phase products to react with other products to form charcoal [10-11]. Some types of reactors can be used for pyrolysis, including those involving high heat and mass transfer rates, namely spouted, and fluidizedbeds, both bubbling beds (BFB) and circulating beds (CFB). Moreover, these technologies (BFB, CFB) present an important problem related to the solid fraction. These reactors use hot solid media in order to achieve high heat transfer coefficients through solid/solid collisions, leading to attrition phenomena and producing smooth particles in the resulting pyrolytic solid fraction [12]. Furthermore, these small particles, which are the result of the shrinking/attrition phenomena, hinder the separation process, and hence the liquid fraction contains higher solid concentrations, promoting aging, erosion, blockage and combustion problems [13].

Similarly, it is also possible to find rotary kilns [14], rotating cones [15], cyclonic reactors [16], and the ablative process [17]. Nevertheless, they are among the more complex reactors to operate and require large quantities of inert gas to fluidize the bed media. In addition, providing the enthalpy for pyrolysis through heat transfer becomes increasingly difficult as the reactors are scaled up [18]. Another method is the soil mound or ground cover kiln, which is most often used [19]. They were free of investment costs, requiring only a few poles and sand to cover biomass pyrolysis. However, they was slow (a few days), and produce significant gas/aerosol emissions [20].

In this study, the innovation in pyrolysis technology has been carried out by designing a pyrolysis reactor measuring $2.4 \times 1.2 \times 1.2 \mathrm{~m}$ using a perforated plateso that spreads heat evenly. This results in a more effective method in burning charcoal and efficient in using external fuel. To eliminate environmental damage due to air pollution, the reactor recirculates and burns most of the gas entering the atmosphere. By-products that are captured as distillates through condenser units and tar scrubbers further reduce the potential impact on air quality. Solid products in the form of charcoal were tested for water content, ash content and caloric content according to the methods of ASTM D. 3173-08, ASTM D. 3174-02 and ASTM D.5865-10a, and produced charcoal quality according to SNI requirements. 01-1682-1996 and the Republic of Indonesia Minister of Energy and Mineral Resources No. 47/2006. This requirement must be fulfilled so that the resulting calorific value is high and becomes one of the references to the pyrolysis reactor, which is designed to produce quality charcoal or not. Charcoal characteristics were tested by SEM, FTIR, XRD and BET to compare the charcoal produced in conventional methods with tar scrubber reactors.

\section{Materials and Methods}

\section{Materials}

Coconut shell samples were collected from industrial waste. The preparation of coconut shell charcoal samples consists of the process of raw materials and the process of removing water content. They were cleaned of fibers and then the drying process was carried out to remove moisture content so as not to affect the process of roasting. The drying process was conducted by drying the shells under the sun for 2-3 days [21]. This preparation was carried out for all conventional charcoal and tar scrubber methods.

\section{Methods}

\section{Conventional Method}

The fabrication of coconut shell charcoal was performed with an open combustion system by using second-hand drum media. A small amount of coconut shell was burned and placed in a combustion chamber (drum) and then doused with kerosene. The fire was sprinkled so that coals arose, then coconut shells were put into the drum gradually. During combustion, the volume of charcoal would be reduced so that the shell need to be added to fill the empty space on the drum.

\section{Pyrolysis Method Equipped with Tar Scrubber}

The reactor can be seen in Fig. 1, consisting of a pyrolysis reactor equipped with a tar scrubber. The reactor measuring $2 \times 2.5 \mathrm{~m}$ is equipped with three pipes as the outlet of smoke and a pair of circulating pipes where the non-condensable gas exits directly connected to the rocket stove, while the tar scrubber section was given pressure of $16 \mathrm{kPa}$ and through the venturi section, which can increase the flow rate. 
Liquid smoke was pushed into a tar separator medium. Coconut shells of $400-500 \mathrm{~kg}$ in mass were put into the reactor while the burning process of the wood in the rocket stove was carried out. Inside the reactor we placed a perforated plate with a diameter of $2 \times 2 \mathrm{~cm}$ in 54 pieces. This was done so that the heat generated from the furnace could be evenly distributed. The process of drying was assisted by a blower to accelerate the evaporation of the moisture content found in the coconut shell. The smoke coming from the chimney was observed. After the released smoke was no longer concentrated, it was clearer and then all the smoke pipes were closed. In the circulation pipe where the methane gas exits, when a flame was formed, the furnace door was closed. After the fire went out it indicated that the carbonization process was complete. Finally, the reactor door remained closed and the smoke pipe was opened to speed up the cooling process. After the cooling process was complete, the charcoal was removed and weighed.

\section{Characterization}

\section{Charcoal Yield}

The charcoal yield produced was obtained by calculating charcoal yield. This analysis was conducted to compare the quality of conventional charcoal production with pyrolysis charcoal and the yield obtained.

\section{Proximate Analysis}

Charcoal was characterized by proximate testing. First, the charcoal was crushed and sieved with a size of 100 mesh, so that each measurement was homogeneous. Proximate testing of charcoal includes moisture content (ASTM D. 3173-08), ash content test (ASTM D. 3174-02) and calorific value test (ASTM D.5865-10a).

\section{Fourier Transmission Infra-Red Spectroscopy (FTIR) Analysis}

FTIR spectroscopy was used to analyze the functional groups on the surface of charcoal in the conventional and pyrolysis methods with the spectral range varying from 4000 to $400 \mathrm{~cm}^{-1}$.

\section{Scanning Electron Microscopy (SEM) Analysis}

Surface texture and morphology of coconut shell charcoal were analyzed by Hitachi SU-3500 Scanning Electron Microscopy (SEM), and elementary analyses were performed simultaneously using an EDX spectrometer [22].

\section{X-ray Diffractogram (XRD) Analysis}

X-ray diffraction (XRD) analysis was performed using a Goniometer model diffractometer with $\mathrm{Cu} \mathrm{K} \alpha$

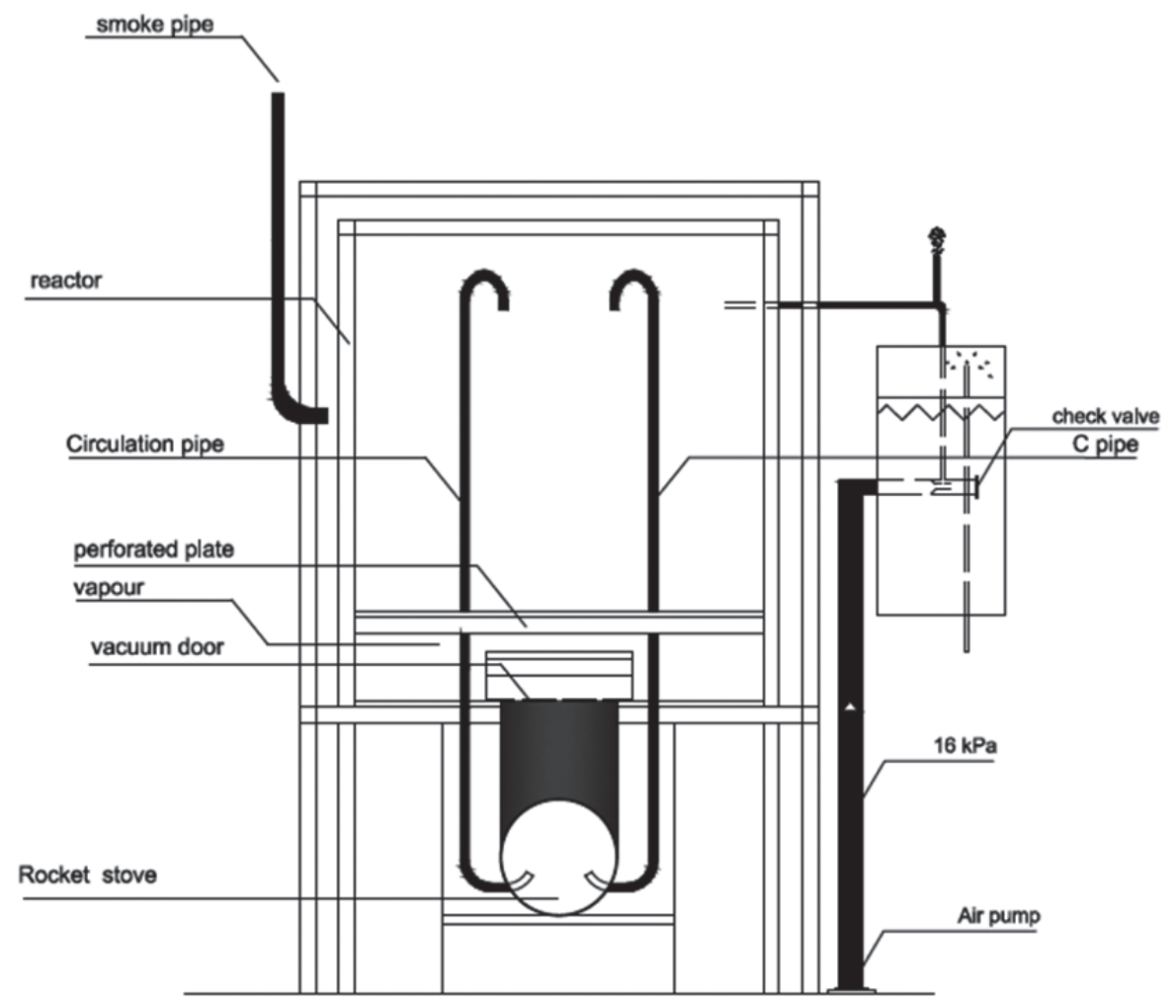

Fig. 1. Details of the tar scrubber pyrolysis reactor. 
( $\alpha=1.54056 \AA)$ radiation to identify the crystal or molecular structure of the material qualitatively [22].

\section{Porous and Surface Area Analysis}

Porous analysis was tested by using the nitrogen isotherm physisorption method (quantachrome autosorb automated gas sorption). Surface area $\left(\mathrm{S}_{\mathrm{BET}}\right)$ was determined from the nitrogen isotherm physisorption data using the Brunauer-Emmett-Teller (BET) method. Total pore volume (VT) is defined as the volume of $\mathrm{N}_{2}$ adsorbed at relative pressure $\mathrm{P} / \mathrm{P} 0=0.99$. Micropore volume $(\mathrm{V} \mu)$ was determined by the equation DubinineRadushkevich (DR), and mesopore volume (Vm) was calculated by reducing the micropore volume of the total pore volume [23].

\section{Results and Discussion}

In this study, the research utilized the noncondensable gas formed. The main components of noncondensable gases are carbon dioxide $\left(\mathrm{CO}_{2}\right)$, carbon monoxide $(\mathrm{CO})$, methane $\left(\mathrm{CH}_{4}\right)$, and hydrogen $\left(\mathrm{H}_{2}\right)$ as reactor fuel sources, making it more economical. This gas is formed due to the decarboxylation and decarbylation reaction [24].

The non-condensable gas formed flows through from the circulation pipe that is connected directly to the rocket stove so that the use of external fuel used is quite economical, around $5 \mathrm{logs}$ of diameter $15 \mathrm{~cm}$ in length $2 \mathrm{~m}$ to completion. The gas combustion process lasts for 3 hours.

The coconut shell casting process was carried out by comparing conventional methods and pyrolysis reactors equipped with tar scrubbers. The observation

a)

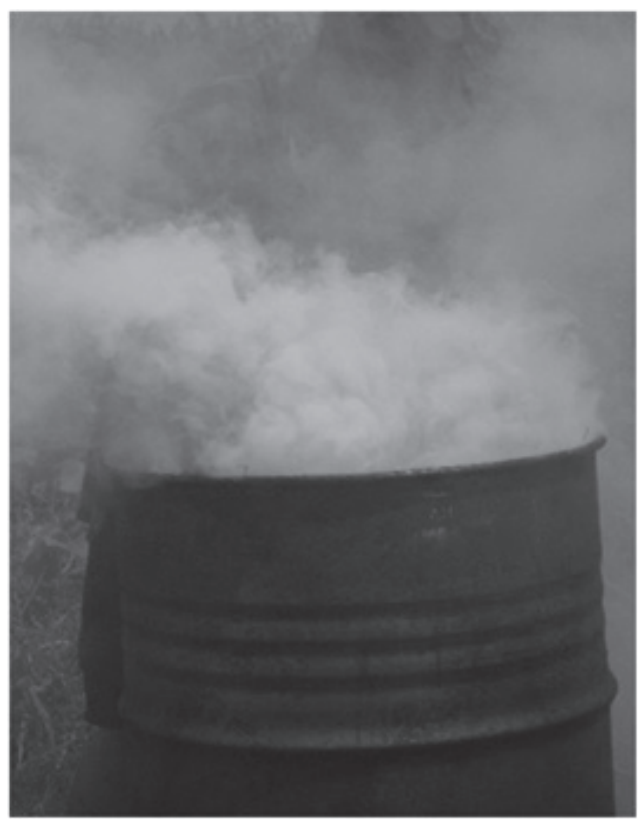

of the appearance of smoke was visually done with the naked eye. It can be compared in terms of colour and the amount of the released smoke. In the conventional method, it is seen that the amount of smoke billowing into the air is yellow and concentrated, covering the combustion area without any control of the smoke exit (Fig. 2a). While the smoke produced from the pyrolysis tar scrubber reactor is thinner. The pipe where the smoke coming out at the pyrolysis reactor can be closed, so that smoke does not come out at all (Fig. 2b).

The smoke produced by the reactor is less because this device is designed tightly and closed, and the presence of a scrubber converts smoke into liquid smoke. The air pump connected to the tar scrubber gives a pressure of $16 \mathrm{kPa}$ and then smoke flows through the venturi suction and pushes smoke into the tar separator medium, which is then condensed. The design of the tar scrubber tool is displayed in Fig. 3. The addition of this tar scrubber tool has a positive impact on minimizing the smoke coming out of the pipe so as to improve the environment-friendly nature.

\section{Charcoal Yield}

The results of the charcoal yield using the conventional method and the pyrolysis tar scrubber reactor are described in Table 1. After the combustion and cooling process was completed, the charcoal was weighed and charcoal yields obtained at the pyrolysis tar scrubber reactor are $28 \%$, with a final weight of $141 \mathrm{~kg}$, while the conventional method produces a yield of $23.8 \%$ with a final weight of $119 \mathrm{~kg}$. The yield of the tar scrubber reactor was higher than the conventional method. The presence of tar scrubbers did not affect the yield of charcoal, but it was seen to increase the yield of charcoal produced.

b)

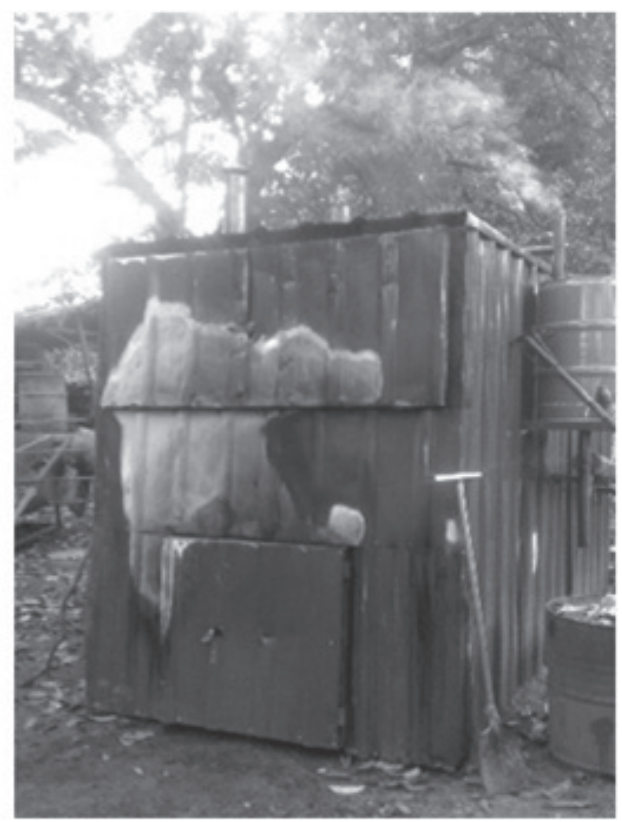

Fig. 2. Smoke produced by: a) conventional method, b) tar scrubber pyrolysis reactor. 


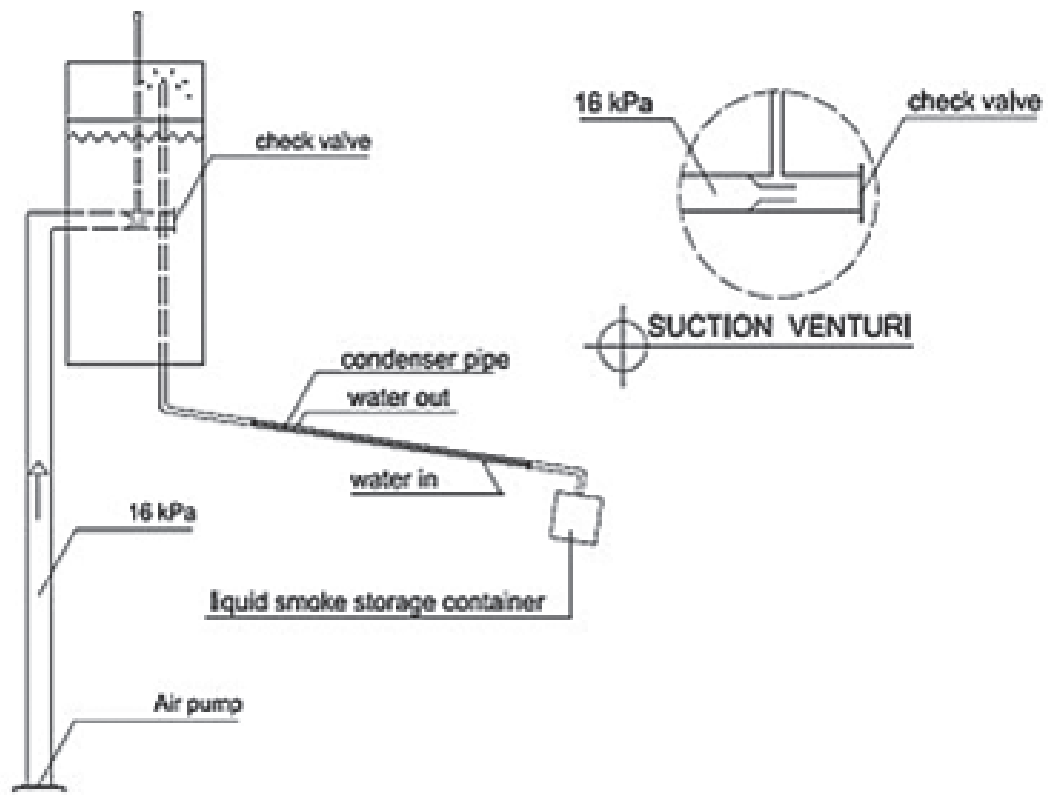

Fig. 3. Design of the tar scrubber.

This is due to the process of pyrolysis, heat energy encourages oxidation, so that the carbon molecules whose complexes break down mostly become carbon or charcoal. The volatile substance content will be lost so that the initial pore structure will be formed and high carbon content is obtained. Carbon content is enhanced by breaking down its chemical bonds so that they can increase energy values and improve their combustion properties. Charcoal provides higher combustion heat and less smoke.

In the charcoal process, carbon is formed well at temperatures between $300-500^{\circ} \mathrm{C}$. Cellulose with a chemical formula $\left(\mathrm{C}_{6} \mathrm{H}_{10} \mathrm{O}_{5}\right)_{\mathrm{n}}$ will be deformed at temperatures of $325-375^{\circ} \mathrm{C}$, while hemicellulose with a chemical formula $\left.\left(\mathrm{C}_{5} \mathrm{H}_{8}\right)_{4}\right)_{\mathrm{n}}$ will be deformed at a temperature of $225-325^{\circ} \mathrm{C}$ and lignin with the chemical formula $\left[\left(\mathrm{C}_{9} \mathrm{H}_{10} \mathrm{O}_{3}\right)\left(\mathrm{CH}_{3} \mathrm{O}\right)\right]_{\mathrm{n}}$ will be deformed at a temperature of $300-500^{\circ} \mathrm{C}$ [25]. In the pyrolysis process, hemicellulose will be the easiest for pyrolysis, then cellulose, while lignin will be the most difficult. Interestingly, both lignin and hemicellulose can affect the characteristics of cellulose pyrolysis [26]. Bio-oil comes mainly from the cellulose component of biomass (around $500^{\circ} \mathrm{C}$ ), whereas solid residue (charcoal) comes from lignin [27]. Based on the number of atoms possessed by the three compounds above, lignin has the most number of carbon atoms while hemicellulose has the least number of carbon atoms [28]. The number of carbon atoms affects the carbon content of the charcoal so that the increase in carbon yield is directly proportional to the temperature of the casting, which causes high charcoal heating values (Table 2).

The charcoal yield produced has a glossy black appearance on the part of the fault. This is due to the carbon element remaining after going through the process of rusting and ringing like metal when hit. The thing that causes charcoal to clink like metal when struck is the very light weight of charcoal coupled with a solid charcoal structure, so that it will produce a loud sound if struck.

\section{Proximate Analysis}

Proximate analysis has been carried out such as moisture content, ash content and testing its caloric content (Table 2) and comparing the results to the quality requirements of the quality of coconut shell charcoal based on SNI. 01-1682-1996, while caloric is based on the Ministry of Energy and Mineral Resources No. $47 / 2006$. We observed that coconut shell water content was reduced from $0.9239 \%$ to $0.2579 \%$. Ash content was also observed to produce a decrease from $2.2601 \%$ to $1.3633 \%$, while the calorific value was observed to increase from $7885,111 \mathrm{cal} / \mathrm{g}$ to $8213.1912 \mathrm{cal} / \mathrm{g}$. It can be

Table 1. Charcoal yield.

\begin{tabular}{|c|c|c|c|}
\hline Method & $\begin{array}{c}\text { The initial weight of coconut shell } \\
(\mathrm{kg})\end{array}$ & $\begin{array}{c}\text { Final weight of charcoal } \\
(\mathrm{kg})\end{array}$ & $\begin{array}{c}\text { Charcoal yield } \\
(\%)\end{array}$ \\
\hline Conventional & 500 & 119 & 23.8 \\
\hline Tar scrubber pyrolysis reactor & 500 & 141 & 28 \\
\hline
\end{tabular}


Table 2. Proximate analysis.

\begin{tabular}{|c|c|c|c|}
\hline Characteristics & Conventional & Tar scrubber pyrolysis reactor & Requirements \\
\hline Moisture content & $0.9239 \%$ & $0.2579 \%$ & Max 6\% \\
\hline Ash content & $2.2601 \%$ & $1.3633 \%$ & Max 3\% \\
\hline Gross calorific value test & $7,885.1191 \mathrm{cal} / \mathrm{g}$ & $8,213.1912 \mathrm{cal} / \mathrm{g}$ & $\mathrm{Min} 3,500 \mathrm{cal} / \mathrm{g}$ \\
\hline
\end{tabular}

seen that the presence of tar scrubbers does not reduce the quality of charcoal.

Moisture content shows the water contained in charcoal, the water content can be affected by the water content contained in the raw material, carbonization temperature and the drying process [29]. From Table 2 we know that the water content in conventional charcoal is higher at $0.9239 \%$ compared to pyrolysis charcoal. This is because the heating temperature causes air humidity to affect the water content, besides which the storage method can also affect absorption. The greater the water content contained, the lower the calorific value. If the water content is high, the time needed to remove the water content will be longer, so the ignition of charcoal will be longer, too. This is because at the beginning of the charcoal burning process, the existing heat will be used to evaporate the water content first, followed by burning the material. In charcoal that is easy to ignite, the water content contained must be low in order to produce high calorific values.

Ash is the residue left after the combustion process. Minerals that cannot be burned will be left behind and become ash, which can reduce the heat value and cause crust on the equipment. The percentage of ash that is allowed cannot be too large. Carbonization conventionally results in high ash content analysis compared to pyrolysis, because conventionally burned coconut shells have a tendency to interact more with air in the environment so that the biomass is decomposed faster to ash [29]. In accordance with Table 2, the ash content in conventional charcoal is higher at $2.2601 \%$ while the pyrolysis charcoal is $1.3633 \%$.

Calorific value is a very important property of charcoal, whih is because the calorific value will determine the feasibility of charcoal to be used as fuel [30]. From Table 2, it can be seen that the higher water and ash contents show a lower heating value. This is because the high temperature of carbonization in charcoal can also affect the heat value produced, the higher the carbonization temperature, the less water content and ash content will decrease. The heat value analysis test on carbonization by pyrolysis shows a higher heating value compared to conventional carbonization. This is due to the optimal use of temperature during carbonization using a tar scrubber pyrolysis reactor. The highest calorific value is seen in pyrolysis charcoal, which is 8,213.1912 cal/gr and $7,885.1191 \mathrm{cal} / \mathrm{gr}$ on conventional carbonization. All samples have met charcoal quality standards.

\section{Fourier Transmission Infra-Red Spectroscopy (FTIR) Analysis}

The FTIR analysis results indicate the vibration of each group formed. Different types of wavelengths produced at each peak occur in coconut shell charcoal in each method (Fig. 4). After analyzing the graph results, an indication of the functional group is performed. The bands at about $3348 \mathrm{~cm}^{-1}$ show vibrations $\mathrm{O}-\mathrm{H}$ in the hydroxyl group [31]. As well as the absorption bands, $1620 \mathrm{~cm}^{-1}$ and $1581 \mathrm{~cm}^{-1}$ indicate that the presence of strain vibrations of carbon groups is a $\mathrm{C}=\mathrm{C}$ ring of aromatic rings [32].

The low frequency value for these bands shows that the hydroxyl group is involved in hydrogen bonds. Band position because the non-bonding $\mathrm{O}-\mathrm{H}$ group is usually above $3500 \mathrm{~cm}^{-1}$ for alcohol, phenol, and carboxylic acids. Seen in the FTIR spectrum charcoal pyrolysis tar scrubbers showed a decrease in the broad intensity of $\mathrm{O}-\mathrm{H}$, which stretched due to partial dehydration. The $\mathrm{O}-\mathrm{H}$ band intensity decreases with increasing pyrolysis temperature with the disappearance of the stretch band $\mathrm{O}-\mathrm{H}$. Another group of $\mathrm{C}=\mathrm{C}$ bonds is in aromatics in $1581-1620 \mathrm{~cm}^{-1}$. Vibration $\mathrm{C}=\mathrm{C}$ is associated with the building blocks of carbon molecules from charcoal [32]. The charcoal tar scrubber charcoal sample has the highest intensity, which shows the highest density of carbon building blocks.

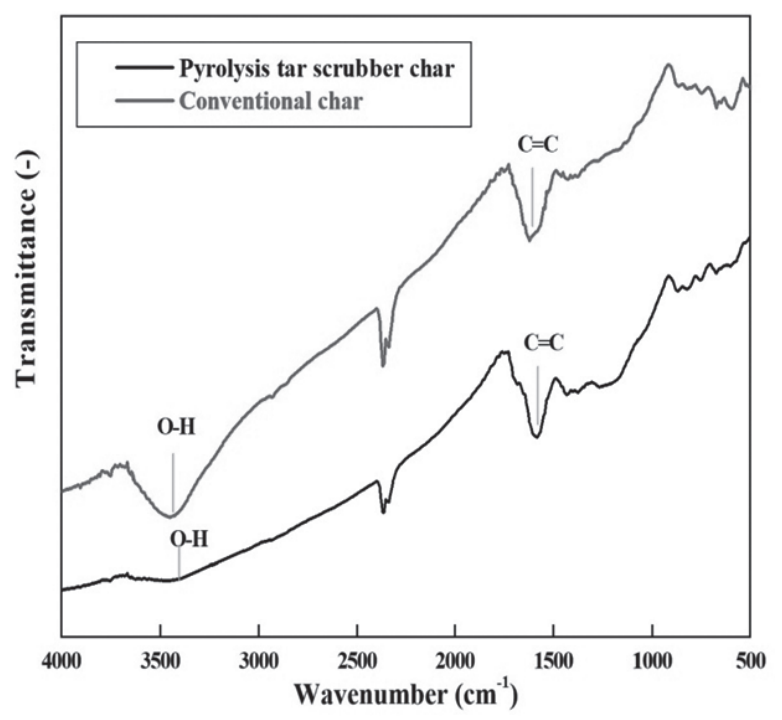

Fig. 4. FTIR spectra and pyrolysis tar scrubber. 


\section{Scanning Electron Microscopy \\ (SEM) Analysis}

The morphological structure of coconut shell charcoal with conventional methods and tar scrubbers was analyzed by SEM. Analysing texture structure and particle morphology of charcoal can be observed from SEM photos at magnifications of $1000 \mathrm{x}, 5000 \mathrm{x}$ and $10000 \mathrm{x}$, which are presented in Fig. 5. The charcoal surface features described by SEM micrographs reveal that the pores of coconut shell charcoal are like fish nets that are structural but not uniform [33]. It was found that the appearance of charcoal pores was greater in the tar scrubber method while conventional produced smaller pores.

a)

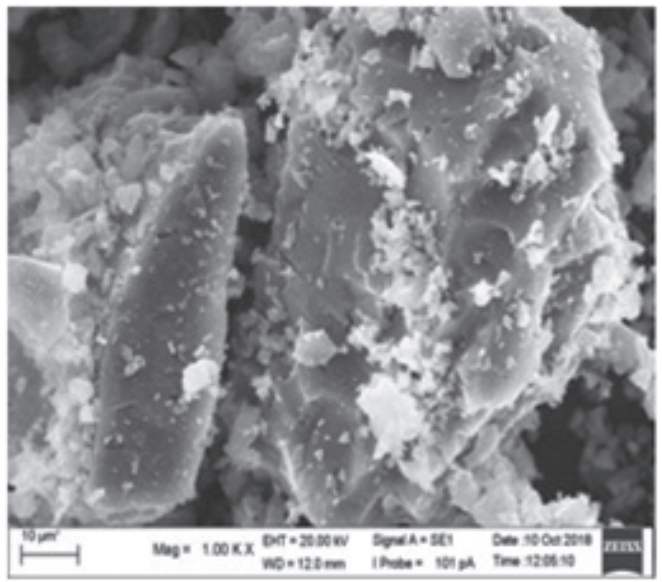

b)
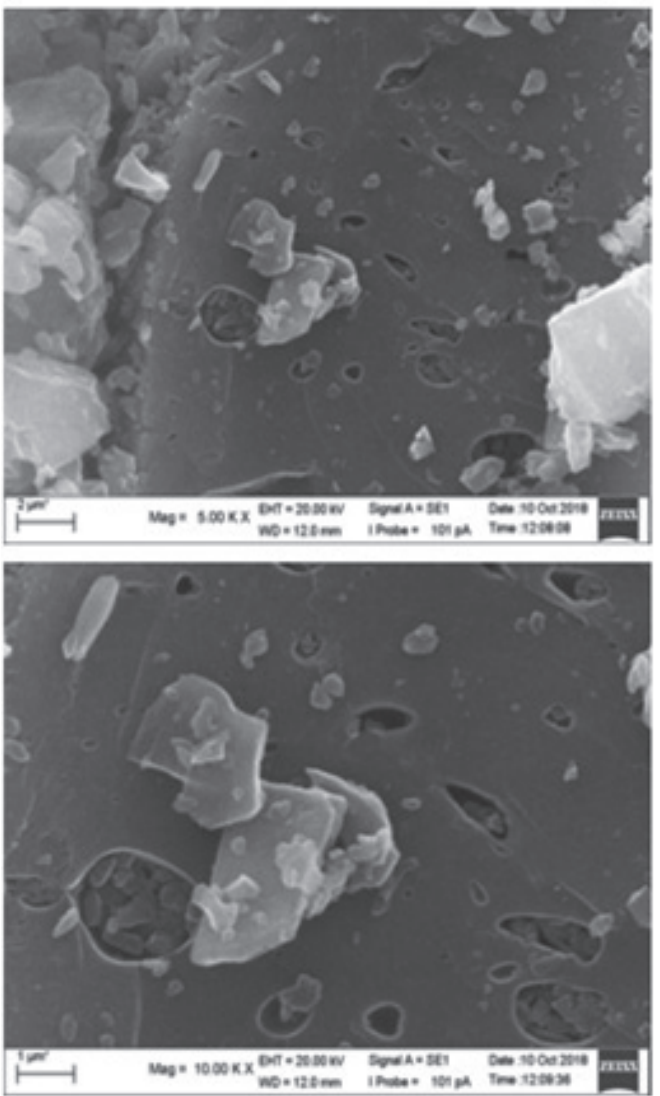

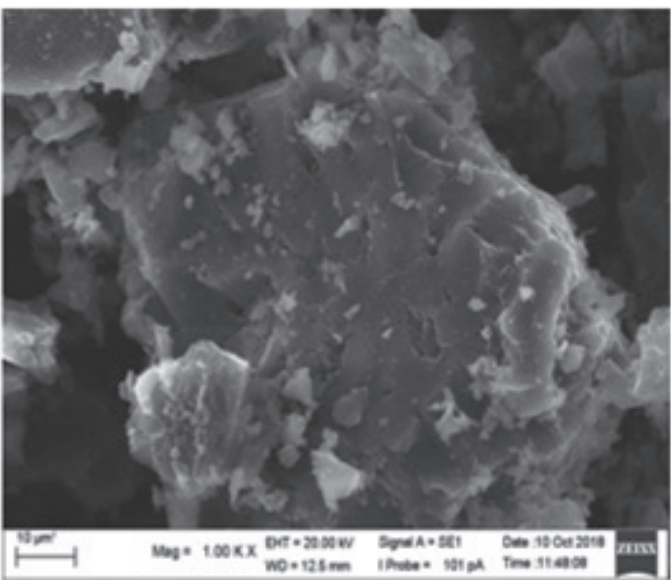

Table 3. Atomic composition of coconut shell charcoal is determined using ED X-ray diffractogram (XRD) analysis.

\begin{tabular}{|c|c|c|c|c|}
\hline Method & $\mathrm{C}(\%)$ & $\mathrm{O}(\%)$ & $\mathrm{K}(\%)$ & $\mathrm{In}(\%)$ \\
\hline $\begin{array}{c}\text { Conven- } \\
\text { tional }\end{array}$ & 81.22 & 17.73 & 0.50 & 0.54 \\
\hline Pyrolysis & 83.61 & 15.73 & 0.23 & 0.44 \\
\hline
\end{tabular}

The identification of the constituent elements of charcoal material was observed using EDS presented in Table 3. Coconut shell charcoal is basically an organic structure with a large amount of carbon and oxygen in its structure [34]. The results showed the
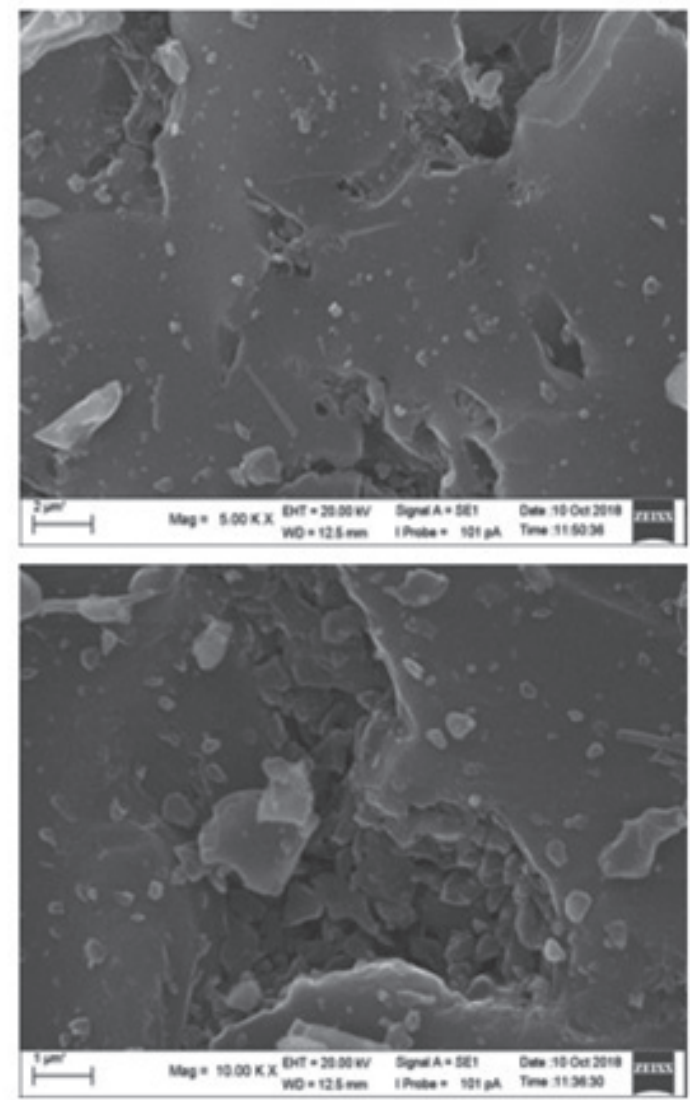

Fig. 5. SEM images of coconut shell charcoal: a) conventional method, b) pyrolysis tar scrubber method. 


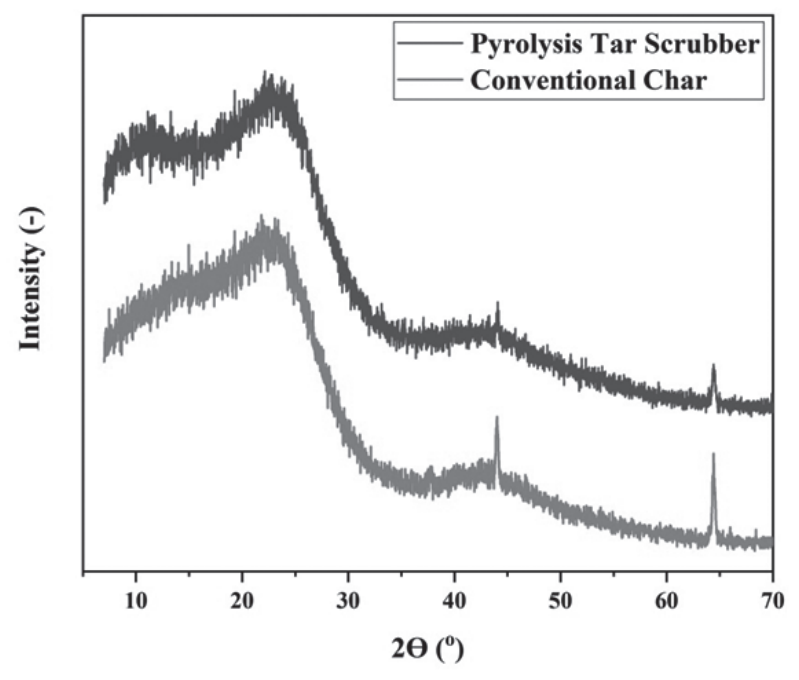

Fig. 6. X-ray diffractogram of charcoal.

main constituent of charcoal material, namely carbon at $81.22 \%$ and $83.63 \%$ and oxygen at $17.73 \%$ and $15.73 \%$, it was seen that there was a reduction in oxygen content in the tar scrubber method. Other minor constituent elements consist of potassium and indium with $0.50 \%, 0.23 \%, 0.54 \%$ and $0.44 \%$ respectively. Minor constituents in conventional charcoal look to be more than tar scrubbers.

Charcoal by the conventional method of pyrolysis contains small bright particles covering the carbon surface (as in Fig. 5a), compared to charcoal by the pyrolysis method not many particles cover the carbon surface (Fig. 5b). These particles come from $\mathrm{K}$ atom impurities in the coconut shell (Table 3). Fig. 5b) shows carbon particles that are denser than pyrolysis charcoal than conventional charcoal. More dense carbon particles are consistent with lower oxygen content (Table 3) [22]. Charcoal carbon content in the tar scrubber method

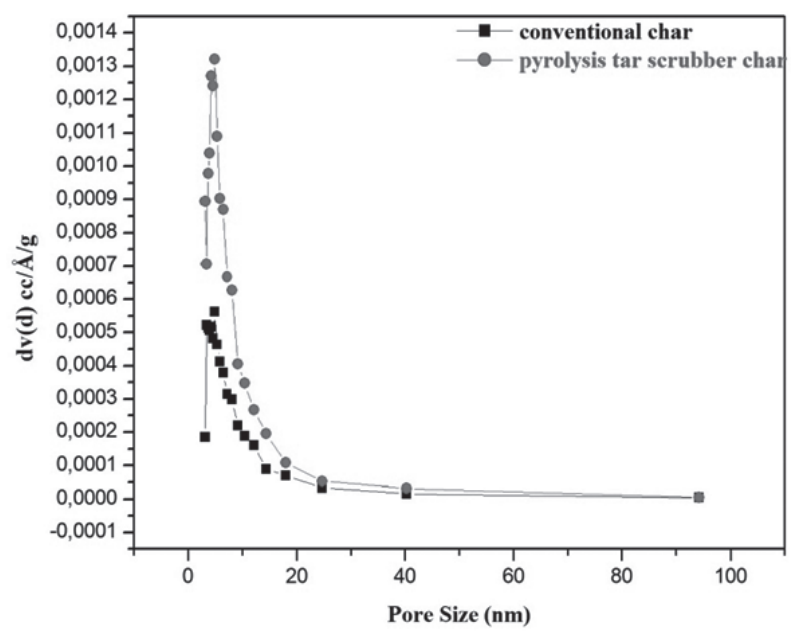

Fig. 7. Comparison of pore size distribution curves in conventional methods and tar scrubbers.
Table 4. Average pore size, total pore volume and surface area.

\begin{tabular}{|c|c|c|c|}
\hline Method & $\begin{array}{c}\text { Average pore } \\
\text { size }(\mathrm{nm})\end{array}$ & $\begin{array}{c}\text { Total pore } \\
\text { volume }(\mathrm{cc} / \mathrm{g})\end{array}$ & $\begin{array}{c}\text { Surface area } \\
\left(\mathrm{m}^{2} / \mathrm{g}\right)\end{array}$ \\
\hline Conventional & 2.30762 & 0.0401 & 6.809 \\
\hline Tar scrubber & 2.3557 & 0.07336 & 12.716 \\
\hline
\end{tabular}

is higher, which proves that this method can increase the carbon element in the charcoal. From the analysis of the carbon content of the pyrolysis process, the higher and longer the pyrolysis time is done, the greater the amount of carbon content of the coconut shell charcoal produced, which is due to the time span of many components of charcoal that are evaporated. The porous structure seen in the pyrolysis charcoal, as illustrated in Fig. 5b), is more open than conventional charcoal (Fig. 5a). From Table 3, it is clearly evident that the charcoal from the tar-scrubber pyrolysis produces larger pores, a greater carbon content of $83.61 \%$ with less oxygen content.

\section{X-ray Diffractogram (XRD) Analysis}

X-ray diffractogram in charcoal is shown in Fig. 6. The charcoal produced has an amorphous structure with peak reflections that widen between $11^{\circ}$ and $30^{\circ}$ [22]. In conventional charcoal we detected $2 \theta=23.32^{\circ}$, while the pyrolysis of scrubber tar was detected at $2 \theta=23.842^{\circ}$. Field diffraction (002) in charcoal structure [35].

These results indicate that the structure of lignocellulosic charcoal is destroyed [36]. The pyrolysis charcoal sample (Fig. 6) has the widest reflection, showing a more amorphous structure. Charcoal consists of carbon along with hydrogen and various inorganic species in two structures: crystalline graphite sheets stacked and amorphous aromatic structures randomly [37]. The tar scrubber method can make the charcoal structure more amorphous than conventional methods.

\section{Porous and Surface Area Analysis}

The characteristics of BJH (Barrett, Joyner, and Halenda) adsorption of the conventional adsorption pore size distribution and tar scrubber is shown in Fig. 7. Average pore size, total pore volume and surface area are presented in Table 4.

From BJH adsorption and desorption data obtained, the highest specific surface area and the highest pore volume were obtained from tar scrubber pyrolysis samples $\left(\mathrm{S}_{\mathrm{BET}}=12.716 \mathrm{~m}^{2} / \mathrm{g}\right)$. In contrast, conventional charcoal samples have the lowest specific surface area of $6.809 \mathrm{~m}^{2} / \mathrm{g}$. This shows that carbonization using tar scrubbers can increase the size and surface area of charcoal pores. A higher specific surface area is consistent with higher micro pore volume. This shows that all charcoal has a material with a high level of micro pore size and is shaped like a gap [38]. 


\section{Conclusions}

Based on this study, the manufacture of charcoal by the pyrolysis tar scrubber method can increase charcoal yield, reduce smoke pollution and improve charcoal quality. The pyrolysis tar scrubber method also utilizes non-condensable gas produced as an external fuel so that it is advantageous on the economic side. The charcoal produced also meets the requirements for quality and meets the characteristics of fuel. The highest pores and charcoal surface area are produced by charcoal with the tar scrubber method.

\section{Acknowledgements}

The authors would like to thank the Ministry of Research, Technology and Higher Education for funding support by a scheme of PMDSU 2017.

\section{Conflict of Interest}

The authors declare no conflict of interest.

\section{References}

1. TURKYILMAZ A., SEVIK H., ISINKARALAR K., CETIN M. Using Acer platanoides annual rings to monitor the amount of heavy metals accumulated in air. Environ. Monit. Assess, 190 (10), 2018.

2. CETIN M., ONAC A.K., SEVIK H., SEN B. Temporal and regional change of some air pollution parameters in Bursa. Air Qual. Atmos. Heal, 12 (3), 311, 2019.

3. SEVIK H., OZEL H.B., CETIN M., ÖZEL H.U., ERDEM $\mathrm{T}$. Determination of changes in heavy metal accumulation depending on plant species, plant organism, and traffic density in some landscape plants. Air Qual. Atmos. Heal, 12 (2), 189, 2019.

4. TURKYILMAZ A., SEVIK H., CETIN M., AHMAIDA SALEH E.A. Changes in heavy metal accumulation depending on traffic density in some landscape plants. Polish J. Environ. Stud, 27 (5), 2277, 2018.

5. WANG B., HANG HO S.S., FAI HO K., HUANG Y., SING CHAN C., YAU FENG N.S., SAI IP S.H. An Environmental Chamber Study of the Characteristics of Air Pollutants Released from Environmental Tobacco Smoke. Aerosol Air Qual. Res, 12, 1269, 2012.

6. SOOCH S.S., GAUTAM A. Present Status of Renewable Energy Sources in Punjab. Int. J. Agric. Environ. Technol, 6 (2), 317, 2013.

7. CETIN M. A change in the amount of $\mathrm{CO}_{2}$ at the center of the examination halls: Case study of Turkey. Stud. EthnoMedicine, 10 (2), 146, 2016.

8. POMYKAŁA R., MAZURKIEWICZ M. Properties of Coal Gasification Wastes Essential to Determining Their Impact on the Environment. Polish J. Environ. Stud, 24 (5), 2147, 2015.

9. LOHRI C.R., RAJABU H.M., SWEENEY D.J., ZURBRÜGG C. Char Fuel Production in Developing Countries - A Review of Urban Biowaste Carbonization.
Renewable and Sustainable Energy Reviews, 59, 1514, 2016.

10. CHEN W., LIAO X., WU Y., LIANG J.B., MI J., HUANG J., ZHANG H., WU Y., QIAO Z., LI X., WANG Y. Effects of different types of biochar on methane and ammonia mitigation during layer manure composting. Waste Manag, 61, 506, 2017.

11. UDDIN M.N., TECHATO K., TAWEEKUN J., RAHMAN M.M., RASUL M.G., MAHLIA T.M.I., ASHRAFUR S.M. An Overview of Recent Developments in Biomass Pyrolysis Technologies. Energies, 11, 3115, 2018.

12. GUPTA M., MCFARLAN A., NGUYEN L., PRETO F. Design and Development of a Novel Centrifuge Ablative Pyrolysis Approach for Biomass Conversion to Bio-Oil and Bio-Char. E3S Web Conf, 61, 1, 2018.

13. BRIDGWATER A.V. Review of Fast Pyrolysis of Biomass and Product Upgrading. Biomass and Bioenergy, 38, 68, 2012.

14. ALONSO E., GALLO A., ROLDÁN M.I., PÉREZRÁBAGO C.A., FUENTEALBA E. Use of Rotary Kilns for Solar Thermal Applications: Review of Developed Studies and Analysis of Their Potential. Solar Energy, 144, 90, 2017.

15. ALIAN M., EIN-MOZAFFARI F., UPRETI S.R., WU J. Using Discrete Element Method to Analyze the Mixing of the Solid Particles in a Slant Cone Mixer. Chem. Eng. Res. Des, 93, 318, 2015.

16. DE JOANNON M., SABIA P., SORRENTINO G., BOZZA P., RAGUCCI R. Small Size Burner Combustion Stabilization by Means of Strong Cyclonic Recirculation. Proc. Combust. Inst, 36 (3), 3361, 2017.

17. LUO G., CHANDLER D.S., ANJOS L.C.A., ENG R.J., JIA P., RESENDE F.L.P. Pyrolysis of Whole Wood Chips and Rods in a Novel Ablative Reactor. Fuel, 194, 229, 2017.

18. CAMPUZANO F., BROWN R.C., MARTÍNEZ J.D. Auger Reactors for Pyrolysis of Biomass and Wastes. Renewable and Sustainable Energy Reviews, 102, 372, 2019.

19. MARTÍNEZ J.D., PUY N., MURILLO R., GARCÍA T., NAVARRO M.V., MASTRAL A.M. Waste Tyre Pyrolysis - A Review. Renewable and Sustainable Energy Reviews, 23, 179, 2013.

20. SMEBYE A.B., SPARREVIK M., SCHMIDT H.P., CORNELISSEN G. Life-Cycle Assessment of Biochar Production Systems in Tropical Rural Areas: Comparing Flame Curtain Kilns to Other Production Methods. Biomass and Bioenergy, 101, 35, 2017.

21. RAMPE M.J., TIWOW V.A. Fabrication and Characterization of Activated Carbon from Charcoal Coconut Shell Minahasa, Indonesia. Journal of Physics:Conference Series, 2018.

22. ROSI M., VIRIDI S. Reduction the Oxygen Content of the Coconut Shell Char Produced by Using Simple Pyrolysis Method. IOP Conf. Ser. Mater. Sci. Eng. 395, 2018.

23. ADEKOLA F., AYODELE S., INYINBOR A. Efficient Rhodamine B Removal Using Acidand Alkaline-Activated Musa Paradisiaca Biochar. Polish J. Environ. Stud, 28 (5), $1,2019$.

24. SINGH R.K., RUJ B. Time and Temperature Depended Fuel Gas Generation from Pyrolysis of Real World Municipal Plastic Waste. Fuel, 174, 164, 2016.

25. ZHOU H., LONG Y., MENG A., CHEN S., LI Q., ZHANG Y. A Novel Method for Kinetics Analysis of Pyrolysis of Hemicellulose, Cellulose, and Lignin in TGA and MacroTGA. RSC Adv, 5 (34), 2015. 
26. CHEN Z., HU M., ZHU X., GUO D., LIU S., HU Z., XIAO B., WANG J., LAGHARI M. Characteristics and Kinetic Study on Pyrolysis of Five Lignocellulosic Biomass via Thermogravimetric Analysis. Bioresour. Technol, 192, 441, 2015.

27. ROY P., DIAS G. Prospects for Pyrolysis Technologies in the Bioenergy Sector: A Review. Renewable and Sustainable Energy Reviews, 77, 59, 2017.

28. DENG J., XIONG T., WANG H., ZHENG A., WANG Y. Effects of Cellulose, Hemicellulose, and Lignin on the Structure and Morphology of Porous Carbons. ACS Sustain. Chem. Eng, 4 (7), 3750, 2016.

29. SAID M., JOHN G., MHILU C., MANYELE S. The Study of Kinetic Properties and Analytical Pyrolysis of Coconut Shells. J. Renew. Energy, 1-8, 2015.

30. CAPUNITAN J.A., CAPAREDA S.C. Assessing the Potential for Biofuel Production of Corn Stover Pyrolysis Using a Pressurized Batch Reactor. Fuel, 95, 563, 2012.

31. RAFIQ M.K., BACHMANN R.T., RAFIQ M.T., SHANG Z., JOSEPH S., LONG R.L. Influence of Pyrolysis Temperature on Physico-Chemical Properties of Corn Stover (Zea Mays 1.) Biochar and Feasibility for Carbon Capture and Energy Balance. PLoS One, 11 (6), 2016.

32. SIENGCHUM T., ISENBERG M., CHUANG S.S.C. Fast pyrolysis of coconut biomass - An FTIR study. Fuel, 105, 559, 2013.
33. ANGALAEESWARI K., KAMALUDEEN S.P.B. Production and characterization of coconut shell and mesquite wood biochar. International Journal of Chemistry Studies, 5 (4), 442, 2017.

34. SUMAN S., GAUTAM S. Pyrolysis of coconut husk biomass: Analysis of its biochar properties. Energy Sources, Part A Recover. Util. Environ. Eff, 5 (4), 442, 2017.

35. MA Z., YANG Y., MA Q., ZHOU H., LUO X., LIU X., WANG S. Evolution of the chemical composition, functional group, pore structure and crystallographic structure of bio-char from palm kernel shell pyrolysis under different temperatures. J. Anal. Appl. Pyrolysis, 127, 350, 2017.

36. ROUT T., PRADHAN D., SINGH R.K., KUMARI N. Exhaustive Study of Products Obtained from Coconut Shell Pyrolysis. J. Environ. Chem. Eng, 4 (3), 3696, 2016.

37. ZHOU H., XIAO G., WU R., HUANG L., NI M., GAO X., CEN K. Influence of temperature on the structure of lignin conductive charcoal graphitization. J. Zhejiang Univ. (Engineering Sci.), 48 (11), 2066, 2014.

38. GODLEWSKA P., SCHMIDT H.P., OK Y.S., OLESZCZUK P. Biochar for composting improvement and contaminants reduction. A review. Bioresource Technology, 246 (10), 193, 2017. 